\title{
Tertium comparationis w przekładoznawstwie
}

\section{Tadeusz Piotrowski}

Wyższa Szkoła Filologiczna we Wrocławiu

\section{Zagadnienia definicyjne}

Tertium comparationis (dalej będę też używał skrótu TC) to termin klasycznej retoryki, używany przy opisie figury retorycznej, zwanej porównaniem (comparatio), jak np. 'dziewczyna jak łania'. TC to pewna wspólna cecha semantyczna, motywująca porównanie i stanowiąca jego podstawę (Głowiński i in. 1988: $377)^{1}$. Zapewne w zacytowanym porównaniu wspólną cechą jest gracja, smukłość ${ }^{2}$ łani i dziewczęcia. Użycie tego terminu zostało rozszerzone na studia kontrastywne i porównawcze różnych języków naturalnych, nie tylko jednego. Poszerzono także jego zastosowanie - podstawę porównania, w różnych podejściach, nie musi stanowić znaczenie. Szerzej o tym będę mówił w dalszej części rozdziału. Najogólniej rzecz ujmując, koncepcja Tertium comparationis w badaniach kontrastywnych zakłada, że relacja między dwoma językami nie jest nigdy bezpośrednia, ale jest zapośredniczana (mediated) właśnie przez odpowiednie TC. Przykładowo, gdy tłumacz słyszy wypowiedź w języku angielskim, używa czegoś, TC, co sprawia, że potrafi utworzyć wypowiedź w języku polskim identyczną, jak chcą niektórzy autorzy (jak np. Jaszczołt 2003), czy też analogiczną (jak np. Haas 1962) pod pewnymi względami, np. semantycznym, do wypowiedzi angielskiej. Większość znanych mi koncepcji zakłada takie pośredniczenie.

Problem TC można rozpatrywać z dwóch różnych punktów widzenia: badacza i praktyka. Badacza zajmuje pytanie: 'Co pozwala stwierdzić, że jednostki

\footnotetext{
${ }^{1}$ Uwaga porządkowa: w wielu wypadkach, cytując prace, korzystam z wersji elektronicznych, które nie odpowiadają formalnie kopii drukowanej. Wszystkie takie prace są odnotowane w bibliografii. Jednak nie podaję z tego względu dokładnej lokalizacji cytatu.

${ }^{2}$ Przy facecyjnych użyciach taką cechą może być płowość, kosmatość etc., co ma być zabawne ze względu właśnie na nieoczekiwaną, niekonwencjonalną cechę semantyczną.
} 
dwóch języków, L1 i L2 ${ }^{3}$, są podobne, pod jakim względem podobne?'. Praktyk stawia sobie pytanie: 'Na jakiej podstawie mogę utworzyć (znaleźć) jednostkę języka L1, aby odpowiadała jednostce języka L2?'. Termin 'jednostka' jest na razie używany w sposób zamierzenie niejednoznaczny, nie odpowiada jedynie jednostce leksykalnej, np. wyrazowi, może odpowiadać tekstowi. Para jednostek języka L1 i L2, odpowiadających sobie pod jakimś względem, nazywana jest często ekwiwalentami, a relacja zachodząca między nimi zwana jest ekwiwalencją. Badaczem byłby lingwista zajmujący się porównywaniem języków, praktykiem - tłumacz lub leksykograf. W niniejszym tekście, jak to określa tytuł, zajmę się względami praktycznymi, odnosząc się jednak także do koncepcji teoretycznych, choćby dlatego, że potrzeb praktyków zwykle nie określano do tej pory jako bardzo odmiennych od względów teoretycznych. Jednak, jak można sądzić, są to dwa odmienne problemy.

\section{Tertium comparationis $\mathrm{w}$ teorii i praktyce}

Zwięźle tę odrębność można scharakteryzować następująco. Badacza interesuje porównywanie języków, które można określić jako porównywanie systemów językowych (por. Lewandowska-Tomaszczyk 1999) ${ }^{4}$. Praktyka interesują teksty w dwóch językach, które można wytworzyć. Badacza zajmuje bezkontekstowa potencja systemów językowych ${ }^{5}$, praktyka zaś stworzenie tekstu sytuowanego w danym kontekście. Od razu może wyjaśnię, że w mojej koncepcji w leksykografii, a w danym przypadku w słowniku dwujęzycznym, nie zachodzi bezkontekstowe porównanie jednostek leksykalnych dwóch języków ${ }^{6}$, choć tak może się z konwencji zapisu słownikowego wydawać. Słownik dwujęzyczny jest skrótowym zapisem analizy pewnej ilości sytuowanych tekstów w obu językach, jest zapisem pewnej nieprecyzyjnej dyspozycji tłumaczeniowej: w pewnych kontekstach języka L2 dany element leksykalny $\mathrm{m}$ o ż $\mathrm{n}$ a zastąpić przez element języka $\mathrm{L1}^{7}$.

\footnotetext{
${ }^{3}$ Te skróty to umowne nazwy języków, L1, pierwszego, ojczystego, L2 drugiego, obcego.

${ }^{4}$ Nie dyskutuję tu z pojęciem 'system języka', aczkolwiek można sądzić, że jest to pewna idealizacja, o której następnie zakłada się, że jest empirycznym obiektem. Inaczej mówiąc, byłaby to hipostaza. Moim zdaniem, język jest zbiorem idiolektów (por. też Davidson 1992).

${ }^{5}$ Wyjaśniam od razu, że w moim przekonaniu także pragmatyka zajmuje się bezkontekstową potencją, ponieważ interesują ją mechanizmy użycia języka w dowolnym kontekście.

${ }^{6}$ Można jednak odnieść to także do leksykografii jednojęzycznej.

7 Zapewne większość lingwistów nie zgodziłaby się ze stwierdzeniem Willarda Van Ormana Quine'a (1997: 95): „Znaczenia są dla leksykografa czymś absolutnie nieistotnym”. Bardziej rozbudowaną argumentację o słowniku jako maszynie tekstowej zob. w: Piotrowski (2001: 44-49).
} 
Jest jeszcze jedna różnica między podejściami teoretycznym i praktycznym. Teoretyk może przestać się interesować zagadnieniem TC, i tak się właśnie niedawno stało, natomiast dla praktyka jest to zawsze palący problem. Otóż najwyraźniej teoretyków w dużej mierze przestała interesować problematyka językoznawstwa kontrastywnego. Od lat dziewięćdziesiątych XX wieku obserwuje się znacznie mniejsze zainteresowanie lingwistyką kontrastywną, a, co za tym idzie, TC (por. Lewandowska-Tomaszczyk 1999). Sprawiło to wiele czynników, np. lingwistyka kontrastywna, przynajmniej w Polsce, była w zasadzie oparta na koncepcjach Noama Chomsky'ego. Od lat osiemdziesiątych notuje się znaczny spadek zainteresowania tymi koncepcjami, choćby ze względu na słabości metodologiczne, brak istotnych wyników, prymat ideologii (por. np. Więckowski 2008 i literaturę tam przytaczaną). Wielu lingwistów zainteresowało się tzw. językoznawstwem kognitywnym, w którym panują nieco inne poglądy na relację języka do poznania, umysłu, znaczenia, świata, a co za tym idzie, poglądy na porównywalność języków i TC.

Jednak także w dziedzinach praktycznych, pragmatycznych, np. w translatologii, zainteresowanie TC oraz ekwiwalentami znacznie się zmniejszyło, co może budzić pewne zdziwienie. Co się stało? Spowodowały to także zmienione poglądy na kwestię relacji język (a dokładniej tekst) a znaczenie oraz, pośrednio, na język (tekst) a świat ${ }^{8}$. Anthony Pym (2010: 20) pisze expressis verbis o naiwnych i idealistycznych pojęciach, takich jak Tertium comparationis. Mianowicie obecnie przyjmuje się dość powszechnie, że znaczenie nie jest właściwością tekstu, tekst też nie ma stałego znaczenia. Znaczenie tekstu bowiem jest właściwością interpretującego go podmiotu, np. czytelnika, wobec tego zależy od umiejętności interpretacyjnych, hermeneutycznych, owego podmiotu, opartych na jego wiedzy o świecie, natomiast składnikami takiej wiedzy są także tradycje literackie, kulturowe. Można powiedzieć, że podmiot tworzy reprezentację intencji twórcy tekstu. W bardziej radykalnych podejściach interpretujący nie tworzy reprezentacji intencji, ale tworzy (konstruuje) znaczenie tekstu na podstawie jego formy oraz swych umiejętności i wiedzy. Można wysunąc stąd logiczny wniosek, że w takim razie każdy tekst ma tyle znaczeń, ile jest podmiotów interpretujących ${ }^{9}$. Od razu trzeba powiedzieć, że nie dla wszystkich badaczy - w tym dla mnie - interpretujący ma całkowitą wolność,

${ }^{8}$ Bardzo trafnie owe zmiany światopoglądowe przedstawia Lawrence Venuti (red. 2004) w serii wprowadzeń do poszczególnych działów antologii tekstów teoretycznych na temat tłumaczenia (por. także Pym 2010).

${ }^{9} \mathrm{~W}$ leksykografii dwujęzycznej nie zauważono najwyraźniej zmiany pojmowania znaczenia, nadal stosuje się w niej sztywne kategoryzacje ekwiwalentów, jakby odnosiły się do stałych, o mierzalnej 'pojemności', znaczeń, leksykografia obecna jest jednak osadzona pojęciowo na gruncie bardzo przestarzałych poglądów na język. 
ale jest on ograniczony tym, co jest określane jako normalny tekst $\mathrm{i}$ jego normalne odczytanie. Normalne odczytanie będę nazywał schematem interpretacyjnym $^{10}$. (Wyraz 'schemat' jeszcze się pojawi w tych rozważaniach).

Tłumacz natomiast ma bardziej skomplikowaną pracę do wykonania: po utworzeniu owego znaczenia tekstu w L2 'zapisuje' je w L1 ${ }^{11}$. Na jakiej podstawie tworzy tekst w L1? Co jest wobec tego Tertium comparationis? Ten problem jednak teoretyków obecnie nadmiernie nie nurtuje. A przecież jest to bardzo doniosłe zagadnienie $w$ przypadku szkolenia tłumaczy. Tłumacz dojrzały wykonuje swoją pracę intuicyjnie, adeptowi tej sztuki trzeba uświadomić pewne podstawowe zasady, opisując je jednak w sposób możliwy do wykorzystania w praktyce. A względy praktyczne spowodowały, że zająłem się tym zagadnieniem.

Są i względy inne. Mianowicie da się jednak zaobserwować pewne zainteresowanie sprawami TC (por. Lewandowska-Tomaszczyk 1999; Jaszczołt 2003; Grzegorczykowa 2009; Pawelec 2010). Co prawda, czytając nowsze prace, doznaje się nader często uczucia dejá $v u$, ponieważ do wielu z nich można zastosować od dawna znane argumenty krytyczne, np. Williama Haasa (1962) czy Andrzeja Bogusławskiego (1976a; 1976b). Zwięzłym przedstawieniem krytyki tych poglądów zajmę się w dalszej części rozdziału.

Niniejszy tekst wpisuje się $\mathrm{w}$ takie powroty. Jest on bowiem zmodernizowaną koncepcją, którą przedstawiłem w książce Problems in Bilingual Lexicography (Piotrowski 1994). Zmiany nie są duże, bowiem w trakcie tych lat nie zapoznałem się z takimi poglądami na Tertium comparationis, które nakazywałyby mi radykalnie zmienić tę koncepcję, nawet przy uwzględnieniu opisywanych zmian w językoznawstwie teoretycznym i stosowanym ${ }^{12}$. Nadal może też służyć w praktyce. Sądzę także, że choć jest ona przede wszystkim praktyczna, pragmatyczna, zawiera też elementy, które można by rozwinąć teoretycznie. Pewne pomysły naszkicuję w końcowej części rozdziału. W obecnym tekście skupię się na jej zastosowaniu w tłumaczeniach, nie tylko dlatego, że pierwotnie

\footnotetext{
${ }^{10}$ Wyrazu 'schemat' używam za terminem Quine'a 'schemat tłumaczenia' (scheme of translation), ekwiwalentnego do wyrażenia 'podręcznik przekładu' (manual of translation; por. Kirk 1986: 32; 'podręcznik' nasuwa zbyt natrętnie skojarzenia z książka), w rozszerzonym jednak znaczeniu: normalny sposób postępowania przy danej czynności, w danym okresie i danej kulturze. Czynnością byłaby np. interpretacja czy tłumaczenie, czy uprawianie nauki. Modniejszym wyrazem byłby termin 'paradygmat', właśnie dlatego jednak go unikam.

${ }^{11}$ Używam dobrze znanego terminu 'znaczenie', jednak nie sądzę, że tłumacz 'tworzy' jakiś obiekt mentalny.

${ }^{12}$ Dla prostoty zaliczam tu tradycyjnie tłumaczenia i słownikarstwo do językoznawstwa stosowanego, choć sam się z takim poglądem nie zgadzam.
} 
została utworzona i opisywana dla potrzeb leksykografii dwujęzycznej, więc jej zastosowanie $\mathrm{w}$ translatologii może być interesujące, ale też dlatego, że jej zmodernizowany opis $\mathrm{w}$ zastosowaniu właśnie do słownikarstwa znajdzie się w tomie redagowanym przez Wojciecha Chlebdę (w przygotowaniu).

\section{Kryteria doboru Tertium comparationis}

Jakie cechy powinno mieć TC, by nadawało się do użycia praktycznego? Za Bogusławskim (1976a; 1976b; por. też Piotrowski 1994) można wyróżnić dwa zasadnicze kryteria. Pierwsze, praktyczne - tłumacz powinien umieć się posłużyć TC bez konieczności przeprowadzania studiów teoretycznych, powinno być ono intuicyjnie oczywiste $\mathrm{i}$ do zastosowania od razu ${ }^{13} \mathrm{w}$ praktyce. Drugie, TC powinno być wystarczająco zewnętrzne w stosunku do obu języków, L1 i L2, tak by nie używano jako TC kategorii wychodzących z jednego języka. To, jak się wydaje, dość zdroworozsądkowe kryteria. Nietrudno jednak zauważyć, że większość TC opisywanych w literaturze po prostu ich nie spełnia. Poniżej przedstawię główne TC, powołując się jedynie na najnowsze prace, odwołania do prac wcześniejszych (i zarzuty krytyczne) znajdują się w cytowanej literaturze.

\section{Tertium comparationis $w$ literaturze}

Otóż często za TC przyjmowany jest jakiś obiekt, znajdujący się albo na zewnątrz języka i podmiotu mówiącego, albo w podmiocie mówiącym (i często uważany za zewnętrzny w stosunku do języka). Dokładniej, w pierwszym przypadku TC to będzie obiekt, do którego odnosi się wyrażenie znaczące, tj. denotat czy odnośnik (referent) w świecie pozajęzykowym, w szczególności w świecie fizycznym, czyli obiekt fizyczny czy układ obiektów. W drugim przypadku będzie to pojęcie etc., ogólnie mówiąc, pewien obiekt mentalny (zgodnie z szeroko przyjętym założeniem, że znaczenie językowe jest zapośredniczane przez obiekt mentalny, czyli właśnie pojęcie). Szczególnym przypad-

\footnotetext{
${ }^{13} \mathrm{O}$ praktycznych wymogach instrukcji, czyli teoretycznego opisu, dla leksykografa por. też Bogusławski (1988: 11): ,program jego [słownika] opracowania musi być 'dla ludzi' - mianowicie nie dla cudotwórców, lecz zwykłych leksykografów”. To samo można powiedzieć o Tertium comparationis dla tłumaczy.
} 
kiem obiektu mentalnego są pojęcia teoretyczne, używane przy opisie języka, czyli pojęcia metajęzykowe.

Jeśli chodzi o pierwsze kryterium, TC jako obiekt fizyczny, można od razu przytoczyć radykalny pogląd Quine'a (1960; por. też uaktualniony skrócony opis w Quine 1997), że tłumaczenie nie jest zdeterminowane empirycznie, co prowadziło do tezy, że język nie jest zdeterminowany empirycznie ${ }^{14}$. Tłumaczenie może być wykonywane dzięki istnieniu 'podręcznika tłumaczeń' czy schematu tłumaczenia:

Podręcznik przekładu [...] stanowi rekurencyjną (czy indukcyjna) definicję r e $1 \mathrm{a} \mathrm{c} \mathrm{j} \mathrm{i} \mathrm{b} \mathrm{y} \mathrm{c} \mathrm{i} \mathrm{a} \mathrm{p} \mathrm{r} \mathrm{z} \mathrm{e} \mathrm{k} \mathrm{ła} \mathrm{d} \mathrm{e} \mathrm{m} \mathrm{wraz} \mathrm{z} \mathrm{twierdzeniem,} \mathrm{że} \mathrm{koreluje} \mathrm{on} \mathrm{zdania}$ w sposób zgodny z oczekiwaniami wszystkich użytkowników tych języków. Teza o niezdeterminowaniu przekładu głosi, że twierdzenie to może być prawdziwe w każdym z dwóch podręczników przekładu [...], a mówiąc inaczej: zdania języka polskiego, przyporządkowane przez dwa różne podręczniki danemu zdaniu języka z dżungli jako jego przekłady, mogą nie być wzajemnie wymienialne w polskich kontekstach (Quine 1997: 81).

Paradoksalna teza Quine'a, jak to rozumiem, stanowi jeden z argumentów na rzecz poglądu, że nie ma obiektów mentalnych w rodzaju znaczeń, są to dyspozycje behawioralne. Sądzę, że ten pogląd jest słuszny. Ma on dalekosiężne implikacje, którymi zajmować się tu nie możemy i nie będziemy (por. Steiner 1975; Kirk 1986). Na ile się orientuję, nie wykazano, że jest błędna ${ }^{15}$. Propozycje np. Donalda Davidsona (1992) rozwiązania problemu nie odnoszą się do relacji język - świat czy też formy językowe a dane empiryczne, a do postaw uczestników aktu komunikacji. Reasumując, koncepcja Quine'a stawia pod znakiem zapytania odwoływanie się do 'czystych' danych sensorycznych, empirycznych, przy ustalaniu możliwego TC. Co więcej, wskazuje, że ekwiwalencja między jednostkami L1 a L2 zależy od danego schematu tłumaczenia,

\footnotetext{
${ }^{14}$ Dokładnie underdetermined, określone (zdeterminowane) w zbyt małym stopniu.

${ }^{15}$ Jaszczołt pisze, że zdaniem niektórych filozofów, obiektywne (?) tłumaczenie nie jest możliwe, według Quine’a tłumaczenie zależy od schematu tłumaczenia, a przecież powszechnie przyjmuje się, że sądy (propositions) są niezależne od języka. Tym samym niejako wykazuje niesłuszność poglądów Quine'a. Jaszczołt popełnia tu pewien błąd logiczny. Mianowicie, aby wiedzieć, jaki sąd został wyrażony przez użytkownika, muszę wiedzieć, jaki sąd wyraża dana forma językowa. I właśnie tego nie jestem w stanie powiedzieć, opierając się na dostępnych mi danych empirycznych, jak rozumiem Quine'a. Jaszczołt omawia przypadek, gdy już wiem, jak przetłumaczyć dane zdanie, tak więc pozostaje w krok za Quine'em. Nie mówiąc o tym, że interpretacja tego, czy na nasze pytanie udzielona została odpowiedź twierdząca lub przecząca przez członka diametralnie obcej kultury, nie jest banalnie prosta.
} 
czyli nie ma stabilnej relacji (poza danym schematem) między jedną jednostką a drugą.

W szczególności zaś nadal pozostają słuszne argumenty strukturalistyczne przeciwko traktowaniu obiektów fizycznych jako determinantów znaczenia wyrażeń językowych. Renata Grzegorczykowa pisze np. o „obiektywnie wyróżniających się fragmentach świata" jako TC. Na ile wiemy, fragmenty świata są wyróżniane przez dany język (czy, szerzej, kulturę) ${ }^{16}$, nie są 'obiektywnie' wyróżniające się wobec innych, wobec tego takie TC nie jest zewnętrzne wobec obu języków, jest oparte zbyt wyraźnie na jednym z nich, w którym takie wyróżnienia są dokonywane.

Podobne TC, według Andrzeja Pawelca (2010), przyjmuje się w językoznawstwie kognitywnym. „Tertium comparationis to 'świat fizyczny' i funkcjonowanie "człowieka gatunkowego"”. Słusznie jednak pisze on, że owa naturalistyczna koncepcja

[...] zbyt ściśle wiąże 'środki językowe' z 'naocznością' czy 'zmysłami' - pomija specyfikę języka jako sposobu kolektywnego 'ujawniania' [...] wizja języka jako 'zestawu środków orientacyjnych' jest zbyt formalna - oderwana od tego, co język pozwala ujawnić bądź czemu pozwala 'dojść do głosu' (Pawelec 2010: 31).

Poza tym, czy doprawdy mamy do czynienia w owych koncepcjach ze światem fizycznym? Można sądzić, że ów świat fizyczny to tak naprawdę pewien model świata, sposób reprezentacji owego świata przez użycie kategorii teoretycznych, metajęzykowych. Zakłada się, że owe kategorie są uniwersalne, ponieważ fundowane są na podłożu biologicznym. Tak naprawdę więc TC „kognitywne” to pewna koncepcja metajęzykowa.

Dość popularne jest przyjmowanie jako TC obiektów mentalnych, zwłaszcza pojmowanych w duchu platońskim, czyli bytów uniwersalnych, istniejących poza językiem. Takie byty to np. pojęcia. Jeżeli jednak zdefiniować pojęcie raczej jako konstrukt umysłowy, pamięciowy, a mianowicie jako pamięć o kontekstach, językowych i pozajęzykowych, występowania danej formy językowej, a co więcej, jako możliwość użycia tej formy, na mocy analogii i indukcji, w innych kontekstach ${ }^{17}$, wówczas jasne się staje, że pojęcie nie jest uniwersalne, dane pojęcie mogę opisać jedynie na gruncie danego języka

\footnotetext{
${ }^{16}$ Oczywiście wchodzimy tu w kwestię relatywizmu językowego i, ogólnie, odniesienia języka do świata, a dokładniej relacji kategorie językowe a poznanie. Jak się wydaje, obecnie znowu coraz donośniejsze są głosy na rzecz relatywizmu językowego (por. np. Boroditsky 2001, 2003, Duranti w druku).

${ }^{17}$ Podobne koncepcje można znaleźć u Haasa (1962), Hoey (2005) czy Teuberta (2004).
} 
(i kultury), nie mogę go używać do opisu innych języków ${ }^{18}$. W przypadku tego TC, znów, można powiedzieć, zakładana uniwersalność kategorii semantycznej to pochodna koncepcji teoretycznych. I tak Grzegorczykowa (2009) postuluje używanie jako TC abstrakcyjnego ,jądra semantycznego", które opisuje cechy wspólne całej opisywanej grupie zjawisk. Jednak takie jądro pojawi się jedynie przy opisie zjawisk językowych z punktu widzenia danej koncepcji teoretycznej (np. Wierzbickiej, chętnie przywoływanej w polskiej literaturze). Z punktu widzenia innej koncepcji takiego jądra może nie być.

Wychodząc poza semantykę leksykalną, Katarzyna A. Jaszczołt (2003) utrzymuje, że sądy, które uważa za znaczenia zdania, są niezależne od języka (are language-independent) i mogą stanowić właściwe Tertium comparationis. Abstrahując od faktu, iż nie wszystkie zdania wyrażają sądy, np. pytania, rozkaźniki, formy przypuszczające (więc nie wszystkie mają znaczenie?), to przyjmuję za Quine'em (np. 1997: 124) i Davidsonem (1992: 33), że to nie zdanie jest nośnikiem prawdy (sądu), ale indywidualny akt jego wypowiadania. $\mathrm{W}$ ten sposób unika się np. przypadku, w którym ta sama forma językowa, zdanie, może wyrażać różne sądy, a tym samym unika się różnych paradoksów logicznych. Do Tertium comparationis wskazanego poniżej, które opiera się na kontekście, sytuacji, nadawałyby się zapewne analizy pragmatyczne. Jaszczołt (2003) jednak wskazuje, że kategorie pragmatyczne mają w wielu wypadkach ograniczone zastosowanie.

Reasumując, większość TC można zaliczyć do koncepcji metajęzykowych. Pytanie, jakie sobie stawia teoretyk, który się chce posłużyć taką kategorią metajęzykową, brzmi mniej więcej tak: 'Jak obiekt metajęzykowy $X$ jest realizowany w języku L1 i L2?'.Wszystkie wyżej opisane koncepcje sprowadzają się do próby dojścia do tego, jak dany obiekt jest 'opisywany', jest realizowany, manifestuje się etc. w języku L1 i L2. Jaki jest główny problem z takimi TC? Wspomniałem już, że wymagane jest opanowanie zaawansowanych umiejętności wykonywania analiz metajęzykowych, na które tłumacz nie ma czasu ani, zwykle, umiejętności. Równie istotne jest to, że propozycje użycia jakiejś kategorii metajęzykowej jako TC zwykle ograniczają się do wskazania przykładowych zastosowań, często bardzo wąskich. Przejście od takich zastosowań do użycia danego TC do dowolnego tekstu, w całym jego skomplikowaniu, nadal wymaga dużych zdolności metaanalitycznych ${ }^{19}$.

\footnotetext{
${ }^{18}$ Tak rozumiane pojęcie pozwala wyjaśnić indywidualność ekstensji i intensji pojęć u różnych użytkowników języka, inaczej mówiąc, wariantywność językowa w tym ujęciu jest normą, jak i dynamiczność semantyki (por. np. Croft, Cruse 2005). Pojęcie traktowane jako byt uniwersalny ponadjęzykowy każe traktować wariantywność języka jako dewiację.

${ }^{19}$ Por. np. Lewandowska-Tomaszczyk (1999).
} 


\section{Sytuacja jako Tertium comparationis}

Najpierw omówię swoją koncepcję, później wskażę, w czym jest podobna do obecnych teorii tłumaczenia, zwłaszcza funkcjonalnych ${ }^{20}$. Wskażę także na różnice. Zacznijmy od opisu typowej sytuacji tłumaczenia, w której występuje indywidualny akt wypowiadania. Ów akt niesie sąd, należy więc od niego wyjść. Analizujemy wobec tego sytuację wypowiadania zdania w L2, po czym ma nastąpić jego tłumaczenie na zdanie L1. Patrząc na taką sytuację czysto zewnętrznie, można wyróżnić kilka jej składowych: użytkownika języka L2, użytkownika języka L1, tłumacza między oboma oraz kontekst, w jakim się znaleźli. Częściami tej sytuacji, kontekstu, są formy znakowe (semiotyczne), ze szczególnym uwzględnieniem form języka. Do form znakowych zaliczamy jednak także znaki niewerbalne ${ }^{21}$, np. ubiór i inne oznaki statusu społecznego uczestników (tłumacz jest zwykle niejako neutralny), a także wszelki inny kontekst historyczno-społeczny, jak wiedzę o tym, co doprowadziło do zaszłej sytuacji i co z niej może wyniknąć (np. względy dyplomatyczne, transakcje handlowe, potrzeby turysty etc.).

Jest to sytuacja, w której należy wykonać tłumaczenie, zwykle też wszyscy jej uczestnicy mają jakieś oczekiwania co do tego, jakie tłumaczenie będzie czy powinno byćc ${ }^{22}$. Neutralność tłumacza powoduje, że nie powinien on wygłaszać ani swoich sądów, ani wyrażać swoich oczekiwań czy też emocji. Uczestnicy posługuja się pewnym schematem tłumaczenia ${ }^{23}$. Zwykle jeden z uczestników (lub osoby wskazane przez niego) jest uprzywilejowany wobec tłumacza, mianowicie zleca tłumaczenie, co powoduje, że tłumacz dostosowuje się do jego oczekiwań (schematów), czy to sformułowanych jawnie czy nie ${ }^{24}$. Powyższy

${ }^{20}$ Niniejszy tekst może sprawiać wrażenie, że jest pochodny wobec przywoływanych prac, dlatego pozwolę sobie zauważyć, że moja koncepcja powstała w tych samych latach, lub wcześniej (przed rokiem 1990), co większość cytowanych publikacji.

${ }^{21}$ Tłumacz zwykle zwerbalizuje i przetłumaczy na drugi język np. nieznaną jednemu z uczestników mowę ciała drugiego uczestnika, np. inne sygnały negacji lub potakiwania (jak w bułgarskim).

${ }^{22}$ Jest to ujęcie bardzo podobne do koncepcji 'norm tłumaczeniowych', czyli kryteriów, jakimi tłumacze się posługują przy wykonywaniu swego zajęcia, por. Toury (1995), Chesterman (1997).

${ }^{23}$ Należy sądzić, że, ze względu na to, iż wielojęzyczność jest normą, także ludzie nie żyjący w cywilizacji technologicznej znają dobrze czynność tłumaczenia (albo użycia różnych języków w różnych sytuacjach) i także mają jakieś oczekiwania co do jego normalnego przebiegu i rezultatu.

${ }^{24} \mathrm{Na}$ istotność tego elementu (który nazywa translator's brief) zwraca uwagę Juliane House (1997). 
opis opierał się na prymarnej sytuacji użycia języka, w mowie, ale nadaje się równie dobrze do tłumaczenia pisanego, choć wówczas uczestnicy są oddaleni czasowo-przestrzennie. Dodajmy jeszcze dla porządku, że najmniejszą cząstką tłumaczeniową będzie zdanie ${ }^{25}$, a dokładniej zdanie w konkretnym kontekście, wypowiedzenie. Całostką zaś właściwą tłumaczenia jest cały tekst we właściwych ramach, we właściwym kontekście, czyli dyskurs.

Co w tak opisanej sytuacji tłumaczenia może być użyte jako TC? Nie schemat tłumaczenia, ponieważ zależy on od innych czynników, a w przypadku całkowicie niestandardowej sytuacji czy tekstu brak będzie właściwego schematu, należy go dopiero stworzyć. Jak sądzę, TC to będzie właśnie owa sytuacja, w jakiej tłumacz się znalazł, aczkolwiek nie należy ją traktować jako zbioru obiektów fizycznych i relacji między nimi, wtedy bowiem mielibyśmy podobne problemy jak z każdym innym TC jako obiektem fizycznym, ale raczej jako intuicyjną konceptualizację tłumacza tej sytuacji, czyli umiejętność wyodrębnienia jej najważniejszych cech. W szczególności umiejętność konceptualizacji oznacza, że tłumacz potrafi na podstawie owych cech sytuacji w kulturze L2 znaleźć analogiczną sytuację $\mathrm{w}$ kulturze L1, zaszeregować sytuację, którą właśnie współtworzy za pomocą form werbalnych (za którymi idą określone asocjacje i oczekiwania, typowe dla sytuacji w L1) do typowej sytuacji w L1. Podkreślam, że to do tłumacza należy nadanie sytuacji niezrozumiałej, bo w kulturze i języku L2, cech sytuacji zrozumiałej, w kulturze i języku L1. Im mniej sytuacja jest standardowa lub im bardziej jest ona odległa od kultury L1, tym bardziej tłumacze mogą się różnić w jej zaszeregowaniu.

Słowo wyjaśnienia się należy, dlaczego używam terminu 'sytuacja', choć może lepszym terminem byłby 'kontekst'. Sądzę, że sytuacja jest wyrazem intuicyjnie lepiej zrozumiałym i odnoszącym się przede wszystkim do otoczenia pozajęzykowego, jako pewnego stanu rzeczy, nie zaś do otoczenia językowego, tekstowego, co sugeruje wyraz 'kontekst'.

W danej sytuacji to tłumacz interpretuje, jakie jej elementy, cechy, są ważne i należy na nie zwracać uwagę, a jakie można pominąć. Jest to także ważne rozróżnienie ze względu na słuszną uwagę Quine’a (1997: 67): „wypowiedzi mają zwykle nikły związek z okolicznościami, które im towarzyszą; wszak często wypowiada się projekty i opisuje doświadczenie minione, wcale nie publicznie dostępne". Wypowiedzi miewają nikły związek z okolicznościami, które im bezpośrednio towarzyszą, ale mogą mieć duży związek z konceptuali-

\footnotetext{
${ }^{25}$ To wypowiedź orzeka coś o rzeczywistości. Natomiast w wielu wypadkach tłumacz będzie schodził niżej, do poziomu jednostek leksykalnych, a nawet jednostek diakrytycznych, np. przy tłumaczeniu poezji.
} 
zowanymi sytuacjami, np. wyobrażanymi sobie. Można w tym wypadku zastosować podobny schemat interpretacji, jaki stosują empiryści, w tym Quine, do wyjaśnienia w jaki sposób dziecko uczy się 'znaczeń, ${ }^{26}$ abstrakcyjnych czy odległych od empirycznej rzeczywistości: dziecko zaczyna od stosowania jednostek języka (wypowiedzi) do konkretnych, empirycznych obiektów, a następnie rozszerza stosowalność tych wyrażeń, per analogiam, do obiektów nieempirycznych czy wyobrażeniowych. Podobnie tłumacz umie analogicznie przechodzić (tłumacząc) od sytuacji bardzo dobrze znanych, empirycznie danych, do tych, w których dostrzega jedynie niektóre cechy podobne do atrybutów tych znanych sytuacji.

Sytuacja, czyli TC, tak opisana, jest niewątpliwie zewnętrzna w stosunku do obu języków - w wielu sytuacjach można komunikować się także bez użycia języka - choć je obejmuje. Można powiedzieć, że tekst językowy jest elementem sytuacji, ale ją nie konstytuuje, a raczej jest na odwrót: dobór właściwych (czyli aprobowanych społecznie, skutecznych etc.) form językowych zależy od danej sytuacji. Co ciekawe, w niektórych okolicznościach tłumacz może świadomie wyłączyć się z danej sytuacji, postawić się poza nią, złamać iluzję swojej 'przezroczystości'. Potwierdza tym samym, że jest świadom ram sytuacji i umie poza nie wyjść, traktuje ją jako pewien możliwy świat. Mianowicie gdy jeden z uczestników wypowiada kwestie, z którymi tłumacz się nie zgadza, np. na gruncie etycznym, tłumacz może zdystansować się, używając formuły 'Pan X twierdzi, że... ${ }^{27}$.W tekście pisanym tłumacz może także zdystansować się od przekładanych treści przez użycie przypisów, glos etc.

Jeżeli przyjać, że zadaniem tłumacza z L2 jest stworzenie tekstu w L1, który jest przezroczysty, nie sygnalizuje swej odrębności wobec innych tekstów w L1, wówczas zadanie tłumacza można sformułować następująco (Bogusławski 1976a):

W sytuacji S, kiedy wyrażenie X jest użyte przez użytkownika L2, jakie byłoby najbardziej naturalne wyrażenie Y użyte przez użytkownika L1 (tłumacza)?

Jest to pytanie, na które potrafi udzielić odpowiedzi odpowiednio uzdolniona osoba dwujęzyczna: tłumacz. Jest to ważne rozróżnienie - 'odpowiednio uzdolniona osoba' - istnieją bowiem osoby dwujęzyczne, które nie potrafią tłumaczyć. Tłumaczenie jest kreatywne, użytkownicy języka mają różne

\footnotetext{
${ }^{26}$ Stosuję tę tradycyjną nazwę, aby uniknąc konieczności rozbudowanych wyjaśnień. Oczywiście znaczeń nie ma. Jest pamięć o kontekstach i dyspozycje zachowaniowe.

${ }^{27}$ Przykład zawdzięczam prof. Christine Nord (Łódź, wrzesień 2010).
} 
predyspozycje i zdolności w tym kierunku. Jak się wydaje, spowodowane jest to właśnie specyficznością sytuacji tłumaczeniowej. Otóż sytuacje zwykle nie są symetryczne, ale są one typowe dla danej kultury i danego języka. Wobec tego użycie wyrażenia L1 w sytuacji L2 jest aktem kreatywnym, ponieważ zwykle oba języki nie są w takim samym stopniu składnikami jednej sytuacji, a raczej wyrażenia z jednego języka będą typowe dla danej sytuacji. Inaczej mówiąc, tłumacz nie tyle przepisuje właściwe wyrażenia-odpowiedniki z jakiegoś rejestru, co je tworzy, przez użycie wypowiedzenia odpowiedniego do sytuacji, tak by odbiorca tłumaczenia mógł je zaakceptować.

Co więcej, właśnie określiliśmy pewne kryterium obiektywne dla naszego TC, takie, które można zastosować z powodzeniem do weryfikacji tekstu tłumaczenia bez znajomości koncepcji teoretycznych. Przywołując znowu słowa Quine'a (1997: 68), tłumacz tworzy zdanie, a (kompetentny) „użytkownik danego języka potwierdza zdanie wygłoszone w takich okolicznościach, w jakich sam by je wypowiedział". Oczywiście należy od razu zwrócić uwagę, że przy tekstach bardzo niestandardowych, oryginalnych, nie każdy użytkownik danego języka będzie mógł potwierdzić zdanie, dlatego że może je wypowiedzieć, ponieważ może to wykraczać poza jego kompetencję. Jednak taki użytkownik, zwłaszcza wyedukowany ${ }^{28}$, jest w stanie zaakceptować takie teksty jako potencjalnie istniejące, mogące zaistnieć, w jego języku. Na tym właśnie zasadza się istota tłumaczeń tekstów bardzo oryginalnych, np. literackich.

\section{Sytuacja w teoriach tłumaczenia}

Na rolę sytuacji jako elementu, od którego wychodzi tłumacz, zwracali uwagę twórcy tzw. teorii funkcjonalnych przekładu, np. Christine Nord (2005: 8), która uważa, że tekst oryginału i przekładu jest determinowany przez sytuację, w jakiej są użyte. Jednak dla nich ważniejsza była funkcja tekstu w sytuacji, owa funkcja była traktowana jako TC przez Nord. Logicznie jednak jest sądzić, że zwykle nie sytuację budujemy wokół tekstu, lecz tekst jest elementem sytuacji, wobec tego istotniejsza jest większa całość, sytuacja, to ona narzuca naszą interpretację funkcji danego tekstu. Także Grzegorczykowa (2009) pisze o sytuacji, sugerując, że w przypadku niektórych leksemów należy zrekonstruować „ogólne pole pojęciowe”, „opis ten wymaga rekonstrukcji pojęciowej

\footnotetext{
${ }^{28}$ Wyedukowany użytkownik został nauczony pewnych postaw wobec tekstów, zwłaszcza ich interpretacji.
} 
sytuacji, do której odnoszą się poszczególne leksemy w obu badanych językach". Jest to procedura, w której niejako wyabstrahowujemy leksemy z kontekstu, tekstowego i pozajęzykowego, aby je móc zanalizować - bowiem leksemy nigdy nie występują w izolacji, ale uwikłane w kontekst - a następnie je faktycznie analizujemy, rekonstruując ten kontekst. Wydaje się, że lepiej zaczynać analizę od nadrzędnej całości, czyli od sytuacji. Z drugiej strony z punktu widzenia badacza tłumaczeń wyjście od tekstu jest normalną procedurą, ponieważ badacz ma tekst, z którego powinien właśnie zrekonstruować sytuację. Jednak z punktu widzenia tłumacza prymarna jest sytuacja, pojmowana jako pewien możliwy świat (tworzony przez tłumacza), w który dopiero wpisujemy jeden z jego elementów, znaki werbalne, tekst.

Dlatego też, jeżeli należałoby więcej powiedzieć o sytuacji, choćby po to, by ją jednak zanalizować w konkretnym przypadku jakiegoś przekładu, można sięgnąc do takich koncepcji, które posługują się pojęciem sytuacji, jak wyżej wspomniane teorie funkcjonalistyczne czy też te, które wychodzą np. od teorii rejestrów Michaela A. K. Hallidaya (por. Munday 2001: 89-101). Ponieważ sytuacja, w moim ujęciu, jest przede wszystkim konceptualizacją pewnego fragmentu świata, wobec tego można zapewne także zastosować opisy używane przez językoznawstwo kognitywne, np. schematy, skrypty. Tak faktycznie postępuje Krzysztof Hejwowski (2007, tam też właściwa literatura), aczkolwiek nie wychodzi od sytuacji, ale od pojęć metajęzykowych, jego sugestie wobec tego są, znów, retroaktywne, zwrócone na zrozumienie zaszłych sytuacji tłumaczenia, zgodnie $\mathrm{z}$ pewną koncepcją teoretyczną, nie zaś proaktywne, nastawione na pomoc w przyszłych sytuacjach.

Trzeba także zwrócić uwagę, że w wyżej wspomnianych koncepcjach w większości wychodzi się od tekstu, nie od sytuacji, co zrozumiałe, bowiem dla językoznawcy tekst jest uprzywilejowany. Można jednak także wyjść od takich opisów, w których sytuacja jednak jest nadrzędna, ale język stanowi jej element, jak np. teoria etnografii mówienia Della Hymesa (Gumperz, Hymes 1986; Hymes 1962). I wreszcie można sądzić, że ciekawe byłoby zastosowanie teorii semantyki sytuacyjnej (por. Akman 2006), jak na razie spotkałem jedynie próby jej zastosowania do tłumaczenia maszynowego (Rupp 1989).

\section{Stosowalność a sytuacja}

Sytuacja to zewnętrzny bodziec, służący do wykonania tłumaczenia na podstawie jej konceptualizacji. Jej cechy mogą być wykorzystywane jako TC, jednak oczywiście można zasadnie zapytać, jaki mechanizm językowy pozwala na jej 
stosowanie przy tłumaczeniu ${ }^{29}$ ? Sądzę, że będzie to relacja między językiem a światem, która jest nadrzędna w stosunku do relacji semantycznych, jak odniesienie (referencja), denotacja i sens, a którą John Lyons, jej pomysłodawca, nazywa stosowalnością. Jak wynika z poniższego cytatu, Lyons twierdzi, że ta relacja obejmuje nie tylko relacje semantyczne, ale wszelką relację między językiem a światem, idealnie więc nadaje się do stosowania w przypadku tłumaczeń. Niestety, koncepcji tej dalej nie rozwijano.

Żyjemy w świecie i sami jesteśmy jego częścią. Języka używamy nie tylko po to, aby opisywać [obiekty] w świecie [...], lecz również po to, żeby [obiekty] opanowywać i przystosowywać się do nich w różny sposób [...]. Jeżeli ową trudną do zdefiniowania [w oryginale: ill-defined] szerszą relację między językiem a światem zewnętrznym nazwiemy stosowalnością, to powiemy, że ... [dana jednostka języka - T. P.] jest stosowaln[a] (tzn. może być poprawnie zastosowan[a]) w określonym kontekście sytuacyjnym lub językowym [...] do pewnych indywiduów lub ich cech. Co więcej, stosowalnością można nazwać wszelką relację między elementami lub cechami języka (włącznie z cechami [...] [suprasegmentalnymi]) a bytami lub aspektami świata, w którym język funkcjonuje (Lyons 1977/1984: 208).

Jak wynika z dotychczasowych rozważań, w tłumaczeniu naczelna jest rola tłumacza, jego umiejętności interpretacyjne. Jeżeli zaś język jest zbiorem idiolektów, każdy nieco inny, a tzw. system języka nie istnieje, jak nie istnieje żaden ogólny system osobowości ${ }^{30}$, wówczas można wnioskować, że nie ma ogólnych reguł tłumaczenia. Teoria tłumaczenia musi być $w$ takim razie niedoprecyzowana. Gdyby dało się wyczerpująco sformalizować wszystkie kryteria, wówczas zapewne dałoby się więcej tłumaczeń przekazać systemom komputerowym. Nie sądzę, aby to kiedykolwiek było możliwe, bowiem tekst nie jest zbiornikiem znaczeń, ale tworzy je interpretator, dlatego thumaczenie pozostanie sztuką ${ }^{31}$.

W zaprezentowanym ujęciu brak ściśle określonych obiektów, czy ich klasy, służących jako TC, w odróżnieniu od większości teorii TC w lingwistyce kontrastywnej. Taki obiekt tłumacz tworzy indywidualnie za każdym razem na

${ }^{29}$ Ze względu na ograniczone miejsce nie będę się zajmował tym, jak ten mechanizm działa na poziomie tłumacza. Moje rozumienie tego zagadnienia ma wiele wspólnego z podejściem Dana Sperbera i Deirdre Wilson (1998).

${ }^{30}$ Aczkolwiek można sądzić, że taką superosobowością jest kultura.

${ }^{31}$ Wiele systemów tłumaczenia maszynowego także zasadniczo opiera się na umiejętnościach tłumacza-człowieka. Mianowicie, w skrócie, tłumacz powinien stworzyć najpierw tłumaczenia referencyjne, z których wyprowadza się reguły dla systemu. 
nowo (por. Croft, Cruse 2004: $75^{32}$ ), na podstawie swej konceptualizacji sytuacji, czyli umiejętności znalezienia takich jej cech, które pozwolą mu na znalezienie analogicznej sytuacji w drugiej kulturze. Robi to, używając mechanizmu zwanego stosowalnością.

\section{Bibliografia}

Akman, V. 2006. „Situation semantics”, [w:] K. Brown (red.).

Barwise, J, Perry, J. 1983. Situations and Attitudes, Cambridge, MA: MIT Press.

Bobran, M. (red.), 1976. Problemy językoznawstwa porównawczego, Rzeszów: Wydawnictwo WSP.

Bogusławski, A. 1976a. „Problem ‘tertium comparationis’ w porównaniu lingwistycznym”, Kwartalnik Neofilologiczny 23 (3), 296-303.

Bogusławski, A. 1976b. „Zagadnienie jednostek przekładowych”, [w:] M. Bobran (red.), 41-62.

Bogusławski, A. 1988. Język w słowniku. Desiderata semantyczne do wielkiego stownika polszczyzny, Wrocław: Ossolineum.

Boroditsky, L. 2001. „Does language shape thought? English and Mandarin speakers' conceptions of time", Cognitive Psychology 43 (1), 1-22 (za: http://wwwpsych.stanford.edu/ lera/papers/).

Boroditsky, L. 2003. „Linguistic relativity”, [w:] L. Nadel (red.), 917-921 (za: http://www-psych.stanford.edu/ lera/papers/).

Brown, K. (red.), 2006. Elsevier Encyclopedia of Linguistics, 2nd ed., Oxford: Elsevier.

Carruthers, P., Boucher, J. (red.), 1998. Thought and Language, Cambridge: Cambridge University Press.

Chesterman, A. 1997. The Memes of Translation, Amsterdam: John Benjamins.

Chlebda, W. W przygotowaniu. Na tropach translatów. W poszukiwaniu ekwiwalentów przekładowych wielowyrazowych jednostek języka.

Croft, W., Cruse, D. A. 2004. Cognitive Linguistics, Cambridge: Cambridge University Press.

Davidson, D. 1992. Eseje o prawdzie, języku i umyśle, Warszawa: PWN.

Duranti, A. W druku. „Linguistic anthropology: language as a non-neutral medium”, [w:] R. Mesthrie, (red.) (za: http://www.sscnet.ucla.edu/anthro/faculty/duranti/Nonneutral\%20medium.pdf).

Głowiński, M., Kostkiewiczowa, T., Okopień-Sławińska, A., Sławiński, J. (red.), 1988. Stownik terminów literackich, Wrocław: Ossolineum.

32 „Pogląd, że kategorie pojęciowe to ustalone kognitywne obiekty, o stałych odniesieniach do wyrażeń językowych, dominował i nadal dominuje w psychologii kognitywnej i językoznawstwie. Od niedawna jednak zaczyna się pojęcia rozumieć dynamicznie, zgodnie z czym sądzi się, że tworzone są one w momencie ich zastosowania". 
Grzegorczykowa, R. 2009. „Punkty dyskusyjne w rozumieniu pojęcia językowego obrazu świata - widziane z perspektywy badań porównawczych”, Etnolingwistyka. Problemy języka i kultury 21 (wersja elektroniczna od Jerzego Bartmińskiego).

Gumperz, J. J., Hymes, D. (red.), 1986. Directions in Sociolinguistics: The Ethnography of Communication. Oxford: Blackwell.

Gutt, E-A. 1991. Translation and Relevance: Cognition and Context. Oxford: Basil Blackwell.

Haas, W. 1962. „The theory of translation”, Philosophy, 37, 2208-2228.

Halliday, M., Teubert, W., Yallop, C., Čermáková, A. (red.), 2004. Lexicology and Corpus Linguistics, London: Continuum.

Hejwowski, K. 2007. Kognitywno-komunikacyjna teoria przekładu, Warszawa: PWN.

Hoey, M. 2005. Lexical Priming: A New Theory of Words and Language, London: Routledge.

House, J. 1997. Translation Quality Assessment: A Model Revisited, Tübingen: Niemeyer.

Hymes, D. 1962. Foundations in Sociolinguistics: An Ethnographic Approach, Philadelphia: University of Pennsylvania Press.

Jaszczolt [Jaszczołt], K. M. 2003. „On translating what is said: tertium comparationis in contrastive semantics and pragmatics", [w:] K. M. Jaszczolt, K. Turner (red.), 441-462 (za: http://people.pwf.cam.ac.uk/kmj21/OnTranslating.pdf).

Jaszczolt, K. M., Turner, K. (red.), 2003. Meaning Through Language Contrast 2, Amsterdam: John Benjamins.

Kirk, R. 1986. Translation Determined, Oxford: Clarendon Press.

Lewandowska-Tomaszczyk, B. 1999. „A cognitive-interactional model of crosslinguistic analysis: New perspectives on 'tertium comparationis' and the concept of equivalence", [w:] B. Lewandowska-Tomaszczyk (red.), 53-76.

Lewandowska-Tomaszczyk, B. (red.), 1999. Cognitive Perspectives on Language, Frankfurt am Main: Peter Lang.

Lyons, J. [1977] 1984. Semantyka 1, Warszawa: PWN.

Mesthrie, R. (red.). W druku. The Cambridge Handbook of Sociolinguistics, Cambridge: Cambridge University Press.

Nadel, L. (red.), 2003. Encyclopedia of Cognitive Science, London: MacMillan Press:

Nord, Ch. 2005. Text Analysis in Translation: Theory, Methodology and Didactic Aplication of a Model for Translation-Oriented Text Analysis, Amsterdam: Rodopi.

Pawelec, A. 2010. „Językoznawstwo kognitywne a hermeneutyka”, [w:] P. Stalmaszczyk (red.), 27-40.

Piotrowski, T. 1994. Problems in Bilingual Lexicography, Wrocław: Wydawnictwo UWr.

Pym, A. 2010. Exploring Translation Theories, London-New York: Routledge.

Quine, W. V. O. [1992] 1997. Na tropach prawdy, Warszawa: Spacja.

Quine, W. V. O.1960. Word and Object, Cambridge MA: MIT Press.

Rupp, C. J. 1989. „Situation semantics and machine translation”, [w:] Proceedings of the Fourth Conference of the European Chapter of the Association for Computational Linguistics, Manchester, 308-318. 
Sperber, D., Wilson, D. 1998. „The mapping between the mental and the public lexicon", [w:] P. Carruthers, J. Boucher (red.), 184-200 (za: http://www.dan. sperber.fr/?p=39).

Stalmaszczyk, P. (red.), 2008. Metodologie językoznawstwa. Wspótczesne tendencje $i$ kontrowersje, Kraków: Lexis.

Stalmaszczyk, P. (red.), 2010. Metodologie językoznawstwa. Filozoficzne i empiryczne problemy w analizie języka, Łódź: Wydawnictwo UŁ.

Steiner, G. 1975. After Babel. Aspects of Language and Translation, Oxford: Oxford University Press.

Teubert, W. 2004. „Language and corpus linguistics”, [w:] M. Halliday, W. Teubert, C. Yallop, A. Čermáková (red.), 113-166.

Toury, G. 1995. Descriptive Translation Studies and Beyond, Amsterdam: John Benjamins.

Venuti, L. (red). 2004. The Translation Studies Reader, $2^{\text {nd }}$ ed., New York: Routledge.

Więckowski, P. 2008. „Młot na językoznawców, czyli o metodologii generatywizmu Chomsky'ego", [w:] P. Stalmaszczyk (red.), 43-104. 